\title{
PENANGANAN HUKUM BAGI PASANGAN SUAMI ISTRI KATOLIK YANG "BROKEN-HOME" SELAMA PERIODE AGUSTUS-DESEMBER 2021
}

\author{
Yohanes Servatius Lon \\ Universitas Katolik Indonesia, Jalan Ahmad Yani No. 10, Ruteng, Flores, NTT, \\ 86518. Indonesia \\ e-mail: yohservatiusboylon@gmail.com
}

\begin{abstract}
Abstrak
Artikel ini mendeskripsikan kegiatan pengabdian kepada masyarakat yang dilakukan pengabdi sebagai akademisi pada Universitas Katolik Indonesia Santu Paulus Ruteng sekaligus sebagai Ketua Tribunal Keuskupan Ruteng. Kegiatan PkM yang telah dijalankan adalah melakukan penanganan hukum melalui gelar perkara perkawinan pada lembaga Tribunal Keuskupan Ruteng dari 12 (dua belas) pasangan suami istri Katolik yang mengajukan gugatan terhadap perkawinan yang telah mereka lakukan. Adapun 12 perkawinan dan rumah tangga pasangan suami-istri Katolik yang menjadi klien dari PkM berakhir hancur dan gagal. Keluarga mereka menjadi broken-home, secara factual sudah bercerai/berpisah dan bahkan mereka sudah memiliki pasangan baru. Dari hasil investigasi dan penanganan kasus perkawinan yang dilakukan oleh Lembaga Tribunal Keuskupan Ruteng, ditemukan bahwa perkawinan yang gagal ternyata berakar pada motivasi dasar awal dari pasangan yang menikah yang sejak semula cacat hukum. Hanya saja hal ini tidak dideteksi dengan baik sejak dini, sehingga membawa mereka pada kehidupan keluarga yang tidak harmonis dan pecah. Setelah melewati proses pendampingan terhadap keluarga bermasalah ini, ternyata penanganan pastoral tidak lagi menjanjikan pemulihan perkawinan yang sudah hancur lebur. Maka, salah satu jalan keluar yang dilakukan adalah melalui penanganan hukum. Adapun proses penanganan ini dilakukan setelah pendampingan pastoral tidak dapat menyelesaikan persoalan mereka. Metode penanganan hukum dimulai dari konsultasi, pemeriksaan adminitrasi pengajuan perkara, investigasi kasus, persidangan, pengambilan kesimpulan, pemberian keputusan dan penyampaian keputusan dan konsekuensi hukum dan pastoral lanjutan dari keputusan yang diambil. Dengan penanganan hukum ini pasangan yang bermasalah bisa terbebas dari keterikatan hukum dan masalah perkawinan mereka.
\end{abstract}

Kata kunci: Tribunal; Keuskupan Ruteng; Perkawinan; Katolik; Anulasi

\section{LEGAL AID FOR CATHOLIC BROKEN HOME COUPLES DURING PERIOD AUGUST - DECEMBER 2021}

\begin{abstract}
This article describes the community service activities (PKM) carried out by a servant as an academic at the Indonesian Catholic University of Santu Paulus Ruteng and the Chairperson of the Ruteng Diocese Tribunal. The PkM activities that have been carried out are carrying out legal handling through the title of marriage cases at the Ruteng Diocese Tribunal from 12 (twelve) Catholic married couples who filed a lawsuit against their marriage. The 12 marriages and households of Catholic married couples who were clients of the PkM were destroyed and failed. From the results of the investigation and handling of marriage cases conducted by the Ruteng Diocese Tribunal Institution, it was found that failed marriages were rooted in the initial primary motivation of the married couple who were legally disabled from the start. All the marriages that were handled earlier were invalid and should not have happened. It is just that this is not appropriately detected early on, thus leading them to a family life that is not harmonious and broken. After going through the process of assisting this troubled family, it turns out that pastoral caretakers
\end{abstract}


no longer promise to restore a marriage that has been shattered. So, one way out is through legal action. After pastoral assistance cannot resolve their problems, the handling process is carried out. The legal handling method starts from consultation, administrative examination of case submissions, case investigation, trial, conclusion making, and delivery of decisions and further legal and pastoral consequences of decisions taken. With this legal treatment, troubled couples can be freed from legal entanglements and marital problems.

Keywords: Tribunal; Ruteng Diocese; Marriage; Catholic; Annulation

\section{PENDAHULUAN}

Salah satu sifat Perkawinan Katolik yang sah dan sakramental adalah kekal dan tidak dapat diceraikan oleh siapapun, kecuali oleh kematian (Kitab Hukum Kanonik/KHK Pasal 1141). Perkawinan Katolik dinyatakan sah jika pada saat pengucapan janji perkawinan di hadapan wakil resmi Gereja (pastor paroki atau pastor lain yang mendapat mandat/delegasi) kedua calon pasangan suami isteri memenuhi pelbagai tuntutan hukum Gereja (KHK Pasal 1083-1104). Jika salah satu atau lebih dari tuntutan hukum ini tidak dipenuhi maka perkawinan tersebut potensial bersifat tidak sah (Kancak, 2014; Prodeita, 2019).

Agar sebuah perkawinan menjadi sah, Hukum Gereja Katolik menuntut: (a) adanya kesepakatan nikah yang bersifat personal, bebas, internal, matang, dan bertanggung jawab; (b) tidak adanya halangan untuk menikah pada kedua belah pihak (si lelaki dan si wanita). Halangan yang dimaksud dapat berupa umur belum pas untuk menikah (KHK Pasal 1083), penyakit impotensi (KHK Pasal 1084), adanya ikatan perkawinan sebelumnya (KHK Pasal 1085), perbedaan agama (KHK Pasal 1096), tahbisan (KHK Pasal 1087), Kaul Kekal kebiaraan (KHK Pasal 1088), pernikahan karena penculikan (KHK Pasal 1089), pembunuhan pasangan sebelumnya (KHK Pasal 1090), adanya ikatan hubungan darah yang dekat (KHK Pasal 1091), hubungan semenda (KHK Pasal 1092), kelayakan publik
(KHK Pasal 1093), dan hubungan adopsi (KHK Pasal 1094); dan (c) adanya tata peneguhan nikah, yaitu ada tata cara pengukuhan perkawinan di hadapan wakil resmi Gereja dan terjadi di dalam upacara resmi Gereja. Wakil resmi Gereja merujuk pada uskup, pastor paroki, imam dan diakon yang mendapat delegasi atau awam yang mendapat kewenangan khusus (KHK Pasal 1108-1112) (Bdk. Lon, 2019).

Selanjutnya, perkawinan itu menjadi sakramen jika kedua pasangan yang melakukan perkawinan yang sah beragama Katolik atau Kristen. Jika salah satu atau keduanya tidak dibaptis maka perkawinan tersebut adalah sah namun tidak sakramental (KHK Pasal 1055 \#2).

Banyak kasus menunjukkan bahwa tidak semua calon pasangan suami isteri memenuhi tuntutan aturan Gereja Katolik pada saat menyatakan janji perkawinan di Gereja. Misalnya, pernikahan seorang anak yang belum dewasa tidak memenuhi aturan tentang umur (KHK Pasal 1083), atau orang yang sudah menikah dengan orang lain tidak memenuhi aturan tentang status liber (KHK Pasal 1085), atau seorang Katolik yang menikahi pasangan dari agama lain (nonkristen) tidak memenuhi aturan tentang agama (KHK Pasal 1086), atau mereka yang memiliki hubungan darah yang sangat dekat tidak memenuhi aturan tentang hubungan darah (KHK Pasal 1091), dan sebagainya. 
Selain itu, motivasi perkawinan sering memengaruhi kualitas calon nikah dalam memenuhi tuntutan Gereja Katolik. Ada yang menikah Gereja karena sudah hamil dan mempunyai anak; ada yang menikah hanya karena dipaksa oleh keluarga atau karena motif ekonomi atau jabatan sosial dari calon pasangan. Motivasi perkawinan yang salah atau tidak baik tentunya berpengaruh terhadap ketahanan hidup perkawinan. Lebih dari itu, motivasi perkawinan yang tidak memadai sering menjadi akar dari pelbagai masalah dalam hidup perkawinan sehingga berakhir dengan kegagalan.

Tribunal Keuskupan Ruteng mencatat beberapa di antara begitu banyak jenis masalah dalam hidup perkawinan yang dialami pasangan Katolik di Keuskupan Ruteng. Pertama, percekcokan dan perkelahian antara suami dan isteri karena perbedaan pola pikir, budaya, masalah ekonomi, dan sebagainya. Pada tahap ini, keutuhan dan stabilitas hidup perkawinan tidak goyah. Kedua, masalah tindakan kekerasan (verbal, fisik, seksual, psikologis) antara suami dan isteri, dan atau terhadap anak. Tahap ini, dibutuhkan bantuan pihak luar untuk menjaga stabilitas dan kerukunan hidup perkawinan. Ketiga, perselingkuhan dan ketidaksetiaan satu sama lain. Pada tahap ini, stabilitas dan keutuhan perkawinan sangat terganggu. Beberapa kasus, masalah perselingkuhan dan ketidaksetiaan satu sama lain menyebabkan pasangan suami isteri hidup pisah ranjang. Tidak jarang, masalah ini menyebabkan para pihak (suami atau isteri) hidup bersama pasangan yang baru.

Dampak lebih lanjut dari perkawinan yang bermasalah di atas pun bermacam-macam. Pertama, secara emosional perkawinan yang bermasalah menumbuhkan rasa benci, sakit hati, duka, iri dan menyirnakan perasaan cinta, damai, rukun, nyaman dan sebagainya. Lebih jauh, perkawinan bermasalah menyebabkan luka batin yang menguatkan perasaan ditolak, tidak diakui dan tidak dicintai. Kedua, perkawinan yang bermasalah menyebabkan anak-anak hidup tidak nyaman dan merasa sepi dan ditolak. Perasaan-perasaan ini membuat anak minder dan takut bahkan depresi. Ketiga, perkawinan bermasalah sering menampilkan wajah kegagalan sehingga secara sosial pasangan suami isteri tersebut tidak mendapat tempat yang baik dalam kehidupan bermasyarakat. Keempat, dalam kehidupan bergereja, pasangan suami isteri yang gagal membangun dan mempertahankan hidup perkawinannya sering distigmatisasi sebagai orang yang hidup dalam kegelapan. Mereka tidak mendapat pelayanan spiritual sebagaimana umat lain yang biasa. Kelima, anak-anak dari pasangan hidup yang gagal sering juga mengalami tindakan diskriminasi dari gereja atau negara. Mereka tidak diberi pelayanan sakramen baptis, komunio pertama. Mereka juga mengalami kesulitan masuk sekolah karena tidak adanya surat baptis (Lon, 2019; Lon dan Widyawati, 2017).

Bagi pasangan yang berada dalam situasi dan permasalahan ini kerap kali perkawinan mereka berakhir gagal dan menjadikan keluarga mereka broken home. Suami dan istri berpisah, tidak tinggal serumah lagi, dan bahkan tidak mau lagi berkomunikasi. Banyak di antara mereka juga akhirnya benarbenar mengakhiri hubungan keluarga dan bahkan membangun keluarga baru dengan pasangan baru. Kondisi ini sebenarnya tidak diinginkan namun telah menjadi suatu realita dan pengalaman konkret dari sejumlah pasangan Katolik di Keuskupan Ruteng. Kendatipun mereka adalah keluarga yang gagal, mereka tetaplah umat kesayangan Allah dan anggota Gereja Katolik. Masalah mereka adalah 
juga menjadi masalah Gereja Katolik (Setiyono, 2019). Tentu saja masalah mereka juga menjadi keprihatinan dari dunia kampus. Perguruan Tinggi sebagai lembaga yang ada bersama masyarakat, menjadi bagian dari persoalan masyarakat harus terlibat dalam usaha membantu mereka yang mengalami masalah kegagalan perkawinannya (Lon, 2020).

Salah satu jalan yang dapat dilakukan oleh akademisi adalah melakukan kegiatan Pengabdian kepada Masyarakat $(\mathrm{PkM})$. Artikel ini menjelaskan $\mathrm{PkM}$ yang dilakukan penulis sebagai dosen pengabdi dalam membantu permasalahan perkawinan pasangan suami istri Katolik di Keuskupan Ruteng. Adapun bantuan yang dilakukan oleh pengabdi adalah dengan memberikan bantuan hukum melalui keterlibatan pengabdi sebagai salah satu Hakim dalam Lembaga Pengadilan Gereja Katolik, Tribunal Keuskupan Ruteng.

Tribunal adalah lembaga peradilan agama milik Gereja Katolik. Lembaga ini bertugas memberikan pelayanan dan bantuan hukum atas perkara-perkara Gereja seperti perkawinan, tahbisan, dll. Tribunal berada di bawah kekuasaan seorang Uskup (Beal, 2012; Fenn dan Rossini, 2017). Perangkat Tribunal terdiri dari hakim, jaksa, tim ahli hukum, anggota dan staf administrasi lainnya. Pengabdi yang melakukan $\mathrm{PkM}$ sebagaimana diulas dalam artikel ini berperan sebagai Ketua Tribunal dan sekaligus sebagai Ketua Hakim Tribunal.

PkM ini bertujuan untuk membantu pasangan suami isteri yang menikah secara tidak sah menikah Gereja dan mengalami kegagalan dalam mempertahankan perkawinan mereka. Dengan kegiatan ini, pasangan suami isteri yang gagal tersebut dibebaskan dari ikatan mereka satu sama lain, sehingga mereka bisa menikah lagi dengan pasangan yang baru. Dengan demikian anak-anak pun mendapat pengakuan dari gereja dan mendapat pelayanan sebagaimana mestinya.

\section{METODE PELAKSANAAN}

Bantuan dan penanganan kasus secara hukum adalah salah satu upaya membantu keluarga-keluarga bermasalah untuk bisa memperoleh jalan keluar terhadap masalah ketidakabsahan perkawinan yang menyebabkan keluarga yang dibangun pasangan suami istri tidak kuat dan kokoh. Adapun bantuan hukum yang menjadi bagian dari kegiatan Pengabdian kepada Masyarakat (PkM) ini dilaksanakan melalui beberapa tahapan proses:

Pertama, konsultasi awal yaitu pihak bermasalah berkonsultasi dengan petugas Tribunal. Pada pihak ini tim Tribunal akan menggali apa persisnya masalah yang dihadapi klien. Tujuannya adalah mengenal dengan baik mendalam persoalan perkawinan klien; apakah masalah mereka harus diselesaikan dengan bantuan hukum atau masih bisa diselamatkan dengan bantuan pastoral keluarga dan perkawinan. Kendatipun pasangan yang mengalami masalah menanggap bahwa perkawinan mereka sudah gagal dan tidak dapat dipertahankan lagi, sejauh keluarga itu masih mungkin diselamatkan, maka bantuan pastoral akan diberikan dalam bentuk nasihat, bimbingan, pendampingan rohani dan keluarga atau upaya membuat pasangan kembali rujuk atau berdamai. Namun tidak semua pasangan yang sudah menyerahkan masalah perkawinan mereka pada lembaga Tribunal bisa dipersatukan dan diperdamaikan kembali. Pada umumnya keluarga sudah benar-benar 
tidak bisa dipertahankan lagi karena pasangan sudah berpisah lama dan bahkan sudah memiliki keluarga baru. Kebanyakan bahkan sudah memiliki anak dari perkawinan (penyatuan) baru mereka dengan pasangan lain.

Karena keadaan seperti ini, biasanya bantuan yang diberikan adalah justru dengan bantuan hukum yakni memproses persoalan perkawinan mereka pada lembaga Tribunal dengan maksud jika benar ditemukan cacat hukum pada perkawinan pertama mereka, maka perkawinan itu bisa dianulasi. Demikianlah fungsi tahap konsultasi adalah menentukan tahapan berikutnya.

Jika tahapan ini akan dilanjutkan, pada tahapan konsultasi ini pihak Tribunal memberikan arahan dan bantuan informasi tentang hal-hal yang harus dilakukan oleh yang bersangkutan agar proses penyelesaian perkawinan dapat berjalan.

Kedua, Lembaga Tribunal meminta pihak bermasalah membuat surat gugatan. Agar permasalahan perkawinan dapat dijadikan agenda persidangan Tribunal, harus ada pihak yang melakukan gugatan terhadap perkawinannya. Maksudnya, salah satu dari pasangan itu menggugat keabsahan perkawinannya dengan pasangannya. Di sini pihak tribunal memberikan dampingan tentang cara membuat sebuah gugatan yang memenuhi aturan hukum Gereja. Dengan demikian dapatlah benar ditemukan adanya masalah keabsahan dari perkawinan yang telah dilakukan sebelumnya.

Ketiga, melakukan pemanggilan dan pendekatan dengan mantan pasangan (disebut tergugat) agar berkolaborasi mencari jalan keluar dari masalah perkawinan mereka yang gagal. Pada tahap ini, tugas Tribunal mengeluarkan surat menyampaikan kepada tergugat bahwa penggugat menggugat perkawinan dengan tergugat. Dalam surat yang sama, Tribunal mengajak tergugat untuk berkolaborasi dalam sidang perkara perkawinan mereka. Jika tergugat tidak bersedia maka perkara dapat saja tetap dilanjutkan tanpa kehadiran tergugat.

Keempat adalah tahapan persidangan perkara perkawinan. Pada tahap ini tribunal menggali informasi seputar perkawinan tersebut pada penggugat dan tergugat serta para saksi. Pada tahap ini Tribunal meminita penggugat mempresentasikan riwayat perkawinan sejak pertemuan pertama, masa pacaran, tunangan, keputusan menikah, masa awal pernikahan dan masalah-masalah yang muncul sebelum pemberkatan pernikahan secara Gerejani maupun sesudah pemberkatan pernikahan secara Gerejani.

Tribunal mengingatkan penggugat dan tergugat untuk memberikan informasi yang benar, jujur dan komprehensif. Selanjutnya Tribunal melakukan pendalaman tentang motivasi pernikahan.

Pada tahap persidangan, penjelasan dan kesaksian penggugat bukan satu-satunya informasi yang harus didalami oleh Tribunal. Selain penggugat, Tribunal juga mendengarkan keterangan dari saksisaksi baik saksi yang menguatkan penggugat maupun saksi-saksi yang menguatkan perkawinan yang sah (saksi pro dan kontra). Tribunal juga mendengarkan keterangan dari tergugat dan semua pihak lainnya yang terkait dengan perkawinan pasangan yang disidangkan.

Kelima, tribunal melakukan analisa terhadap semua informasi tentang perkawinan tersebut guna membuat keputusan yang benar dan tepat berdasarkan hukum gereja. Jika data-data persidangan memerlihatkan bahwa perkawinan tersebut memang cacat secara hukum Gereja, maka Tribunal dapat memutuskan bahwa 
keabsahan perkawinan tersebut dicabut atau dianulasi. Artinya permohonan penggugat untuk membatalkan keabsahan perkawinannya dikabulkan. Jika keputusannya demikian, maka secara resmi perkawinan yang pernah dilakukan tersebut di masa lalu, dinyatakan tidak sah. Dengan ini, kedua pasangan itu tidak lagi terikat secara hukum sebagai satu pasangan Katolik (Darmanto dan Dewa, 2021; Lon, 2016).

Tentu saja tidak semua persidangan menghasilkan keputusan anulasi perkawinan. Bisa saja persidangan justru memutuskan bahwa perkawinan yang pernah dilakukan di masa lalu sudah sesuai dengan hukum dan kedua belah pihak harus menghormati asas hukum yang ada.

Keenam, jika keputusan anulasi telah diberikan, maka Tribunal memberikan rekomendasi agar penggugat dan atau tergugat dapat melakukan pernikahan yang baru dengan pasangan yang lain.

\section{HASIL DAN PEMBAHASAN}

Adapun bantuan hukum yang telah dijalankan oleh pengabdi yang dibahas dalam artikel ini dijalankan khusus periode persidangan Tribunal pada Agustus - Desember 2021. Dalam periode ini, Tribunal Keuskupan Ruteng telah menyelesaikan 12 perkara perkawinan, yaitu 4 perkara perkawinan pada bulan Juli, 4 perkara perkawinan pada bulan Oktober, dan 4 perkara pada bulan Desember.

$$
\text { Perlu diketahui proses }
$$

persidangan yang dijalankan pada periode ini sebenarnya adalah perkaraperkara perkawinan yang sudah didaftarkan pada periode sebelumnya. Artinya bantuan dalam bentuk konsultasi hukum pra peradilan sebenarnya juga telah dilakukan sebelum masa persidangan. Hanya saja sebagaimana dijelaskan sebelumnya, ketika masalah yang dihadapi pasangan suami istri tidak lagi dapat diatasi melalui jalan keluar pastoral dan pendampingan keluarga, maka kasus itu dinaikkan statusnya menjadi suatu perkara persidangan.

Persidangan yang dilakukan periode yang dilaporkan ini menangani kasus kegagalan perkawinan Katolik karena aneka alasan. Demi menjamin kerahasiaan identitas pasangan yang diperkarakan, laporan ini dengan sengaja tidak memuat nama klien pengabdi.

Kalau menelisik mengapa pasangan suami istri yang dipersidangkan kali ini gagal membangun rumah tangga Katolik yang baik, alasan paling dominan adalah pada mengapa mereka dulu memilih menikah, atau motivasi pernikahan Katolik yang pernah dilakukan. Semua pasangan yang ditangani periode ini memutuskan pernikahan karena alasan telah melakukan hubungan seks pranikah, yang menyebabkan perempuan hamil dan mempunyai anak. Padahal hubungan seks itu sendiri terjadi ketika pasangan belum benar-benar mengenal pasangan dengan baik dan tidak didasarkan atas cinta dan komitmen untuk hidup bersama.

Pernikahan terjadi karena desakan orantua, serta demi menyelamatkan nama baik. Kehamilan dianggap mencemarkan nama baik keluarga, khususnya keluarga perempuan. Olehnya laki-laki diminta untuk segera menikahi perempuan. Selain itu, bagi perempuan yang hamil, ia memiliki ketakuan diusir oleh orang tuanya, atau bahkan dapat menyebabkan orang tua stress dan sakit. Karena itu, mereka takut orang tua mengalami hal buruk jika tidak 
dilakukan pernikahan. Mereka juga tidak berani untuk menanggung sendiri akikat kehamilan karena tidak berani hidup sendiri dan takut diejek oleh masyarakat. Oleh karena itu, pernikahan adalah jalan keluar.

Demikian pula laki-laki. Mereka sangat takut mendapatkan sanksi dari pihak keluarga perempuan yang kerap mengancam melakukan kekerasan jika tidak segera menikahi perempuan yang telah dihamili.

Di sini jelas bahwa orang menikah bukan terutama karena saling mencintai dan berkomitmen secara sadar dan bertanggung jawab untuk membangun keluarga tetapi terutama karena terpaksa. Pernikahan yang telah dijalankan oleh 12 pasangan adalah pernikahan yang tidak dipersiapkan, tidak dilandasi kesadaran, dan tidak berorientasi pada pembentukan keluarga Kristiani yang sejati. Pernikahan terjadi karena ketakutan, keterpaksaan dan tuntutan eksternal dari pada kerinduan dan komitmen internal. Relasi saling memahami antar keduanya sangat terbatas.

Padahal, KHK Pasal 1057 \#2 menegaskan bahwa kesepakatan nikah haruslah merupakan sebuah perbuatan kemauan antara seorang pria dan seorang wanita untuk saling menerima dan mencintai seumur hidup. Kemauan mereka harus diberikan secara bebas, sadar dan bertanggung jawab. Kemauan mereka harus bebas dari paksaan. KHK Pasal 1103 berbunyi sebagai berikut: Perkawinan adalah tidak sah jika dilangsungkan karena paksaan dan atau ketakutan besar yang dikenakan dari luar, meskipun tidak sengaja, sehingga untuk melepaskan diri dari ketakutan tersebut seseorang harus memilih jalan menikah. Dalam pelbagai kasus, paksaan datang dari pihak wanita terhadap si lelaki dengan cara meminta si lelaki bertanggung jawab terhadap kehamilan pada si wanita. Permintaan tanggung jawab sering disertai dengan ancaman dari pihak keluarga si wanita. Di sini si lelaki tidak punya pilihan selain mengikuti paksaan si wanita karena takut akan ancaman dari keluarga besar si wanita.

Paksaan yang dibicarakan dalam KHK Pasal 1103 sesungguhnya mencakupi paksaan fisik dan paksaan moril. Paksaan fisik biasanya disertai dengan ancaman dari luar yang menyebabkan adanya rasa takut. Misalnya, orang tua memaksa anaknya menikahi orang tertentu disertai ancaman pengusiran dari rumah, pembunuhan, pembakaran rumah dan sebagainya. Paksaan psikologis merupakan sebuah kondisi psikologis di mana yang bersangkutan takut melawan kehendak orangtua atau pihak lain karena akan menyebabkan terjadi hal yang fatal (Lon, 2019).

Motivasi pernikahan yang dangkal dari 12 pasangan yang dipersidangkan dalam periode ini bukan hanya cacat secara hukum yang menyebabkan keabsahan perkawinan mereka diragukan, melainkan juga ternyata menjadi akar ketidakharmonisan rumah tangga mereka. Setelah menikah, berdasarkan hasil investigasi selama persidangan yang dilakukan, 12 keluarga ini tidak menjalankan kehidupan berumah tangga dengan baik dan normal. Ada 2 pasangan yang usia kebersamaan mereka kurang dari satu tahun. Setelahnya keduanya berpisah rumah dan tidak pernah lagi berkomunikasi. Selama setahun perkawinan, relasi keduanya juga tidak harmonis. Mereka sering bercecok dan berkelahi.

Ada tiga pasangan lainnya juga menjalankan kehidupan rumah tangga yang tidak harmonis. Apalagi secara ekonomis, ketika menikah mereka belum memiliki pekerjaan dan menumpang dan bergantung pada orang tua mereka yang juga hidup terbatas. Akibatnya keluarga mereka sering bertengkar dan bahkan terjadi 
kekerasan di dalam rumah tangga. Anak juga bahkan menjadi korban kekerasan orang tua (Lon dan Widyawati, 2017). Hubungan suami istri buruk dan demikian pula hubungan mereka dengan orang tua/ mertua juga tidak harmonis. Kerap kali masalah kewajiban adat seperti mahar/mas kawin (Lon dan Widyayawati, 2018) juga bisa memicu pertengkaran hebat di dalam rumah tangga. Salah satu pasangan, suaminya juga berjudi dan suka bermabuk-mabukan, sehingga menjadi pemicu konflik.

Demikianlah, rumah tangga dan perkawinan yang dibangun sama sekali tidak sesuai dengan hukum perkawinan Gereja Katolik. Perkawinan dilakukan karena keterpaksaan, bukan merupakan pilihan bebas dan juga rumah tangga tidak diwarnai oleh relasi cinta yang saling mendukung atau menghormati satu sama lain.

Padahal dalam keyakinan Kristiani, kebebasan adalah adalah sebuah mahkota dan anugerah istimewa yang diterima manusia dari Tuhan. Tuhan sendiri menghargai kebebasan yang diberikannya kepada manusia. Kisah manusia pertama dalam Kitab Kejadian (3, 1-24) jelas menggambarkan apresiasi Tuhan terhadap kebebasan pada setiap manusia. Kebebasan melekat pada hakikat setiap manusia. Kebebasan bahkan menjadi mahkota keluhuran martabat seorang manusia. Kebebasan membuat manusia tidak saja mengikuti instink dalam hal perkawinan. Dengan kebebasannya seseorang dapat membuat pilihan sesuai dengan kehendak hati nurani dan pertimbangan akal budi yang matang dan sadar serta bertanggung jawab (Lon, 2019).

Dengan demikian kebebasan juga memberikan seseorang hak untuk menikah dan hak untuk tidak menikah.
Bagi yang menikah, haknya dilindungi sebagai hak asasi (Pasal 10 Undangundang RI No 39 Tahun 1999 tentang HAM; Konvensi hak sipil dan Politik Pasal 23). Dari kodratnya setiap orang memiliki kecendrungan untuk hidup bersama orang lain dan membangun relasi personal yang intim dengan lawan jenisnya.

Sebagai HAM, hak menikah tentunya tidak dapat dicabut atau dilanggar. Namun dalam implementasinya, hak menikah diatur sesuai dengan aturan budaya, agama atau negaranya. Di Indonesia, hak menikah diatur menurut ketentuan Undang-undang Perkawinan RI No 1 tahun 1974 tentang perkawinan. Sejalan dengan itu, hak menikah orang Katolik mengikuti ketentuan hukum ilahi dan hukum kanonik. Di dalam Kitab hukum kanonik ditetapkan pelbagai ketentuan yang menjamin hak dan kebebasan setiap orang dalam menikah.

KHK Pasal 1066 mewajibkan pastor paroki untuk memastikan tidak adanya halangan sebelum sebuah perkawinan terjadi, seperti adanya paksaan menikah. Maka sejalan dengan itu, dalam Gereja Katolik diwajibkan adanya penyelidikan kanonik sebelum pengukuhan perkawinan di gereja. Penyelidikan kanonik bertujuan untuk memastikan bahwa kedua calon pasangan tidak mempunyai halangan untuk menkah secara sah. Kedua psangan saling mengenal secara baik, kedua pasangan sehat rohani jasmani, memiliki motivasi nikah yang baik. Dengan adanya pelbagai kasus di atas maka dapat disimpulkan bahwa penyelidikan kanonik berjalan tidak maksimal. Hal itu bisa karena pastor paroki tidak menjalankan sebagaimana mestinya. Dapat juga terjadi karena kedua calon pasangan menipu pastor paroki. Sebagai contoh, kasus 
perkawinan tungku cuu yang terjadi antara pasangan suami isteri asal Manggarai dan dilakukan di kalimantan. Kedua pasangan menceritakan kepada pastor paroki bahwa mereka tidak mempunyai hubungan darah. Padahal, mereka tahu mereka menikah karena hamil.

Setelah rumah tangga 12 pasangan ini hancur, pasangan berpisah. Pasangan-pasangan ini kemudian jatuh cinta dengan orang lain dan kembali membangun hidup berkeluarga tanpa ikatan perkawinan Katolik. Namun, relasi mereka sudah diketahui oleh keluarga besar dalam ikatan adat lokal setempat. Beberapa pasangan baru ini juga sudah memiliki anak dari hasil perkawinan baru. Mereka merindukan agar perkawinan yang menurut mereka sudah dilakukan atas cinta dan motivasi yang lebih murni dapat diberkati oleh Gereja. Namun karena mereka masih terikat

Demikianlah dengan memberikan jalan keluar berupa bantuan dan penanganan hukum, dua belas pasang suami istri Katolik yang dipersidangkan dalam periode Agustus - Desember 2021 tersebut mendapatkan status anulasi perkawinan. Permohonan mereka agar pernikahan yang pernah dilakukan di waktu sebelumnya untuk ditinjau kembali keabsahan dikabulkan. Perkawinan pertama mereka dinyatakan tidak sah, atau dicabut keabsahannya.

Dengan demikian, 12 pasangan tersebut tidak lagi terikat dengan pasangan masing-masing. Mereka sudah dibebaskan dari hak dan kewajiban karena perkawinan yang pernah diterimakan sebelumnya. Dengan ini mereka bisa terbebas dari beban batin maupun beban sosial dan religius. Status ini membuat mereka kembali menjadi "liber" atau merdeka. Dengan demikian mereka bisa mengajukan perkawinan dengan pasangan baru jika mereka menghendakinya dan tentu saja jika sesuai dengan ketentuan hukum yang berlaku.

Dengan demikian, bantuan
dalam bentuk pengabdian kepada masyarakat ini telah juga mencapai tujuannya yaitu dapat membantu pasangan Katolik mengatasi permasalahan rumah tangga mereka.

\section{KESIMPULAN}

Perkawinan Katolik yang ideal adalah yang monogami dan tak terceraikan. Perkawinan Katolik juga harus bersifat legal. Masalah percekcokan, perkelahian, kekerasan dan perselingkuhan sering menerpa kehidupan perkawinan pasangan Katolik. Dalam beberapa kasus, masalah ini menyebabkan banyak pasangan mengalami stigma sebagai orang gagal, pendosa dan olehnya tidak berhak mendapat pelayanan spiritual dari Gereja. Anak-anak mereka sering menderita ketidak adilan karena tidak dibaptis dan sulit masuk sekolah.

Keluarga broken home membutuhkan pendampingan pastoral yang memadai agar perkawinan dapat diselamatkan. Namun masalahnya berbeda ketika akar persoalan justru pada legalitas perkawinan itu sendiri. Perkawinan yang tidak memenuhi aspek hukum dapatlah digugat keabsahannya. Hal ini terjadi pada 12 pasangan yang ditangani Tribunal Keuskupan Ruteng. Bantuan pastoral tidak memadai menyelamatkan perkawinan mereka yang sejak awal sudah tidak memenuhi aspek perkawinan Katolik yang baik dan benar. Olehnya penanganan perkara pengadilan yang berdampak pada anulasi perkawinan menjadi jalan keluar bagi pasangan broken home tersebut.

Olehnya, keterlibatan akademisi dalam gelar perkara sebagai bagian dari

9 | Randang Tana: Jurnal Pengabdian Kepada Masyarakat; E-ISSN: 2622-0636 
PkM ini membantu pasangan. Dengan memperoleh sertifikat anulasi, mereka berhak atas pelayanan kerohanian dan sebagainya.

\section{DAFTAR PUSTAKA}

Bandur, H. (2017). Keluarga Katolik, Mea Dan Sekularitas. Jurnal Alternatif-Wacana Ilmiah Interkulutral, 1(2), 35-60.

Beal, J. P. (2012). Tribunal Vetitum: A Practice in Search of a Theory, the. Jurist, 72, 377.

Darmanto, Ignasius Anang Setia, and Febri Putra Dewa. "Anulasi Perkawinan Dalam Motu Proprio Mitis Iudex Dominus Iesus dari Paus Fransiskus dan Relevansinya Bagi Perkawinan Katolik." Jurnal Pastoralia 2.2 (2021): 49-65.

Fenn, D. L., \& Rossini, E. D. (2017). Roman Catholic Marriage Tribunals: The use of psychological testing in marital annulment proceedings.

Professional Psychology: Research and Practice, 48(3), 211.

Kancak, M. K. L. (2014). Perkawinan Yang Tak Terceraikan Menurut Hukum Kanonik. Lex et Societatis, 2(3).

Laiyan, L. (2021). Strategi Gereja Katolik Dalam Mempersiapkan Dan Mendampingi Pasangan SuamiIstri Demi Kebahagian Keluarga. Jurnal Logos, 1(1), 1522.
Lon, Y. (2016). Anulasi Perkawinan dan Implikasinya Bagi Pastoral perkawinan Katolik. In Prosding Seminar Nasional. Dioma.

Lon, Y. S. (2019). Hukum Perkawinan Sakramental dalam Gereja Katolik. PT Kanisius.

Lon, Y. S. (2020). Program KPPK Di Keuskupan Ruteng Sebagai Upaya Meningkatkan Kesadaran Pasutri Akan Hakikat Perkawinan Katolik. Randang Tana-Jurnal Pengabdian Masyarakat, 3(1), 113.

Lon, Y. S. (2020). Tantangan Perceraian Sipil Bagi Perkawinan Katolik: Antara Hukum Ilahi Dan Hukum Manusia. Jurnal Selat, 7(2), 151168.

Lon, Y. S., \& Widyawati, F. (2017). Lingkaran kekerasan terhadap anak dalam masyarakat manggarai. Jurnal Pendidikan dan Kebudayaan Missio, 9(1), 12-20.

Lon, Y. S., \& Widyawati, F. (2018). BrideWealth: Is There Respect for Women in Manggarai, Eastern Indonesia? Humaniora, 30(3), 271278.

Prodeita, T. V. (2019). Pemahaman dan Pandangan Tentang Sakramen Perkawinan oleh Pasangan Suami-Istri Katolik. Jurnal Teologi, 8(2019), 85-106.

Setiyono, I. A. (2019). Faktor Perceraian dan Upaya Pencegahannya Pada Pasangan Suami-Istri Yang Beragama Katolik Di Pengadilan Negeri Surabaya (Doctoral dissertation, Universitas Katolik Darma Cendika Fakultas Hukum). 